\title{
PENGARUH PROFITABILITAS DAN LIKUIDITAS TERHADAP STRUKTUR MODAL PERUSAHAAN SEKTOR PROPERTY DAN REAL ESTATE DI BEI
}

\author{
Rosita Dewi ${ }^{1}$, Made Suci $^{2}$,AA. Ngurah Yudha Martin Mahardika ${ }^{3}$ \\ 1,2,3 Jurusan Manajemen, Universitas Pendidikan Ganesha, Singaraja \\ e-mail:rode.dewi@gmail.com, madesucibali@yahoo.com, yudhamartin mph@yahoo.com
}

\begin{abstract}
Abstrak
Penelitian ini bertujuan untuk menguji pengaruh profitabilitas dan likuiditasterhadap struktur modal secara simultan maupun parsial. Desain penelitian yang digunakan adalah kuantitatif kausal dan sumber data yaitu data sekunder.Subjek penelitian ini adalah perusahaan sub sektor property dan real estate yang terdaftar di Bursa Efek Indonesia dan objek penelitian adalah profitabilitas, likuiditas dan struktur modal. Data dikumpulkan dengan teknik pencatatan dokumen.Sampel dalam penelitian ini yaitu data keuangan dari 18 perusahaan selama 2 tahun yang di dapat dengan teknik purposive sampling. Kemudian dianalisis dengan analisis regresilinier berganda menggunakan program SPSS 23 for windows. Hasil penelitian menunjukkan bahwa (1) profitabilitas dan likuiditas berpengaruh signifikanterhadap struktur modal dengan besar sumbangan pengaruh yaitu 92,5\%, (2)profitabilitas berpengaruh negatif dan signifikanterhadap struktur modal sebesar38,2\%, (3) likuiditas berpengaruh negatif dan signifikanterhadap struktur modal sebesar $6,7 \%$.
\end{abstract}

KataKunci: profitabilitas, likuiditas, struktur modal.

\begin{abstract}
This study was aimed at examining the effect of profitability and liquidity on capital structure simultaneously or partially. The research design was causal quantitative with data sources, as secondary data. The subjects of this research were property and real estate sub-sector companies listed on the Indonesia Stock Exchange and the object of research were profitability, liquidity and capital structure. Data were collected by document recording technique. The sample in this study was financial data from 18 companies for 2 years obtained by purposive sampling technique. The data were then analyzed with multiple linear regression analysis using SPSS 23 for windows. The results showed that (1) profitability and liquidity had a significant effect on capital structure with a significant contribution of 92.5\%, (2) profitability had a negative and significant effect on capital structure of $38.2 \%$, (3) liquidity had a negative and significant effect on capital structure of $6.7 \%$.
\end{abstract}

Keywords: profitability, liquidity, capital structure. 


\section{Pendahuluan}

Keberadaan perusahaan menjadi faktor yang sangat penting didalam kegiatan bisnis khususnya dalam bidang perekonomian. Tujuan perusahaan yakni mencapai laba yang maksimum sehingga dapat mensejahterakan para pemegang saham dan meningkatkan nilai perusahaan. Peran manajer perusahaan dibutuhkan dalam menunjang produktivitas baik dalam kegiatan produksi, pemasaran,ataupun dalam strategi perusahaan guna memaksimalkan keuntungan perusahaan di tengah persaingan ekonomi global yang sangat ketat. Analis Artha Sekuritas Indonesia Jordan mengatakan, ada beberapa faktor dan sentimen yang menjadi penggerak sektor properti dari sisi harga yaitu pada tahun lalu harga saham sektor ini sudah terkoreksi cukup dalam.

Perusahaan ini memerlukan faktor-faktor pendukung yang kuat khususnya dalam pengelolaan pembiayaan atau pendanaan yang baik gunakedepannyamenunjang kinerjaperusahaan. Sumber pendanaan tersebut dapat diperoleh dari dalam maupun luar perusahaan. Sumber dana internal adalah dana yang dibentuk atau dihasilkan sendiri dari dalam perusahaan yaitu berupa laba di tahan dan akumulasi depresiasi. Keputusan pendanaan perusahaan merupakan salah satu keputusan yang penting yang dihadapi manajer perusahaan dalam kelangsungan operasional perusahaan nanti maka dari itu perusahaan memerlukan adanya suatu kebijakan pendanaan yang tepat. Selain itu, manajer keuangan secara khusus diharapkan dapat memutuskan sumber dan jumlah dana yang digunakan untuk operasional perusahaan agar dana tersebut tidak menimbulkan beban berlebih pada perusahaan. Menurut Sartono (2012: 225) keputusan pendanaan yang dicerminkan melalui struktur modal berkaitan dengan perbandingan besarnya penggunaan hutang oleh perusahaan dengan ekuitas untuk pembiayaan investasi.

Menurut Sukardi dan Christian (2009), struktur modal perusahaan adalah kombinasi dari saham-saham yang berbeda (saham biasa dan saham preferen) atau bauran seluruh sumber pendanaan jangka panjang (ekuitas dan utang) yang digunakan perusahaan. Menurut Muhadi (2011), struktur modal merupakan topik yang komplek dan salah satu faktor yang menentukan nilai perusahaan. Struktur modal digunakan dalam penelitian ini karena untuk mengetahui seberapa besar perusahaan dibiayai oleh utang. Debt Equity Ratio (DER) merupakan rasio yang digunakan untuk mengukur tingkat leverage (penggunaan hutang) terhadap total shareholder's equity yang dimiliki perusahaan. Pentingnya struktur modal bagi setiap perusahaan dikarenakan memiliki efek langsung terhadap posisi keuangan perusahaan sehingga manajer keuangan harus mengetahui faktor-faktor yang mempengaruhi struktur modal agar dapat memaksimalkan kemakmuran pemegang saham perusahaan (Yuliani, 2011). Penelitian ini mengacu pada teori Brigham dan Houston (2001) menyatakan faktor - faktor yang dapat mempengaruhi struktur modal seperti profitabilitas, ukuran perusahaan, pertumbuhan perusahaan, likuiditas perusahaan, tingkat pajak, risiko bisnis, struktur aktiva, leverage operasi, sikap manajemen, fleksibilitas keuangan, kontradiksi juga ditemukan pada variabel likuiditas, yang merupakan salah satu variabel lain yang mempengaruhi struktur modal. Kamaludin dan Rini (2012), yang menyatakan bahwa faktor-faktor yang umummnya dipertimbangkan keputusan struktur modal dalam beberapa literatur keuangan adalah sebelas faktor berikut: stabilitas penjualan, struktur aktiva, leverage operasi, tingkat pertumbuhan, profitabilitas, pajak, pengendalian, sikap manajemen, sikap pemberi pinjaman dan lembaga penilai peringkat, kondisi pasar keuangan, dan fleksibilitas keuangan.Beberapa temuan empiris menampilkan hasil yang berbeda terkait dengan faktor-faktor yang mempengaruhi struktur modal.

Profitabilitas merupakan kemampuan yang dimiliki perusahaan untuk memperoleh laba dalam hubungannya dengan penjualan, total aset maupun modal sendiri (Sartono, 2012:122). Dalam penelitian ini rasio profitabilitas diproksikan pada return on asset(ROA). Rasio ini untuk mengukur tingkat pengembalian investasi yang telah dilakukan perusahaan dengan menggunakan seluruh aset yang dimilikinya. Semakin besar profitabilitas maka semakin baik, karena menunjukkan kemampuan untuk menghasilkan laba dari aktiva yang dimiliki perusahaan. Hal ini didukung oleh penelitian yang dilakukan oleh Watung, dkk. (2016), telah menemukan bahwa profitabilitas berpengaruh positif terhadap struktur modal. Namun tidak 
sejalan oleh penelitian yang dilakukan oleh Stenyverens, dkk. (2018) mengatakan bahwa profitabilitas tidak memiliki pengaruh terhadap struktur modal. Sedangkan penelitian yang dilakukan oleh Dewiningrat, dkk. (2018) menemukan bahwa profitabilitas memiliki pengaruh negatifsignifikan terhadap struktur modal.

Kasmir (2010) menyebutkan bahwa rasio likuiditas (liquidity ratio) merupakan rasio yang menggambarkan kemampuan perusahaan untuk memenuhi kewajiban utang jangka pendek. Dalam penelitian ini rasio likuiditas akan diproksikan pada Current ratio (CR).Current ratio menurut Kasmir (2014) menyatakan bahwa rasio lancaratau (current ratio)merupakan rasio untuk mengukur kemampuan perusahaan membayar kewajiban jangka pendek atau utang yang segera jatuh tempo pada saat ditagih secara keseluruhan. Perusahaan dengan current ratio tinggi mengindikasikan adanya jumlah aktiva lancar yang besar dibandingkan dengan hutang lancarnya.

Dari uraian tersebut, dapat disimpulkan bahwa perusahaan yang memiliki likuiditas tinggi cenderung akan mengurangi atau bahkan sama sekali tidak menggunakan hutang karena memiliki jumlah dana internal yang besar, sehingga lebih memilih untuk memaksimalkan penggunaan atas dana tersebut untuk melunasi kewajiban atau hutang jangka panjangnya karena modal kerja yang dimiliki perusahaan juga tinggi sehingga berdampak pada nilai DER yang turun karena total hutang semakin berkurang. Berdasarkan penelitian yang dilakukan oleh Seftianne dan Handayani (2011) menemukan bahwa likuiditas tidak mempengaruhi struktur modal. Hal ini tidak sejalan dengan penelitian yang dilakukan oleh Watung dkk (2016) menemukan bahwa likuiditassecara parsial berpengaruh negatif terhadap struktur modal.

Berdasarkan latar belakang diatas, terdapat hasil penelitian yang tidak konsisten dan kesenjangan antara teori dengan kenyataan yang terjadi, sehingga perlu dilakukan penelitian kembali. Penelitian ini mengambil data dari Bursa Efek Indonesia yaitu pada perusahaan sub sektor property dan real estate yang terdaftar di BEI menunjukkan bahwa terdapat 18 perusahaan yang telah mempublikasi laporan keuangan secara lengkap dan mengalami masalah yang bertentangan dengan teori. Berdasarkan uraian tersebut maka tujuanpenelitian ini adalah untuk menguji "Pengaruh Profitabilitas dan Likuiditas Terhadap Struktur Modal Pada Perusahaan Sub Sektor Property dan Real Estate Yang Terdaftar di Bursa Efek Indonesia". Dari pemaparan diatas maka dapat dirumuskan hipotesis sebagai berikut.

$\mathrm{H}_{1}$ : Ada pengaruh profitabilitas terhadap struktur modal.

Menurut Weston dan Brigham (2006:173), perusahaan dengan tingkat return on assset yang tinggi, umumnya menggunakan hutang yang relatif sedikit. Profitabilitas merupakan kemampuan yang dimiliki perusahaan untuk memperoleh laba dalam hubungannya dengan penjualan, total aset maupun modal sendiri (Sartono, 2012:122). Dampak dari nilai return on asset yang tinggi adalah menurunnya rasio dari struktur modal karena apabila perusahaan memiliki tingkat keuntungan yang tinggi maka perusahaan tersebut akanmenggunakan laba ditahan yang dimiliki oleh perusahaannya untuk dijadikan sebagai modal perusahaan tersebut sehingga hal ini akan menurunkan nilai dari struktur modal. Jadi dapat disimpulkan bahwa semakin tinggi nilai return on asset maka akan menurunkan nilai dari struktur modal. Penelitian yang dilakukan oleh Watung, dkk. (2016) profitabilitas memiliki pengaruh negatif terhadap struktur modal.

$\mathrm{H}_{2}$ : Ada pengaruh likuiditas terhadap struktur modal.

Menurut Ozkan (2001), perusahaan dengan aset likuid yang besar dapat menggunakan aset ini untuk berinvestasi. Kasmir (2010) menyebutkan bahwa rasio likuiditas (liquidity ratio) merupakan rasio yang menggambarkan kemampuan perusahaan untuk memenuhi kewajiban (utang jangka pendek) sehingga semakin tinggi tingkat Likuiditas berarti memiliki aktiva lancar yang cukup untuk mengembalikan utang lancarnya sehingga memberikan peluang untuk mendapatkan kemudahan dalam memperoleh utang dari investor. Kemampuan perusahaan dapat meningkatkan kepercayaan dari para kreditur untuk meminjamkan dana kepada pihakpihak perusahaan yang membutuhkan modal. Kemampuan tersebut sering disebut likuiditas perusahaan. Jika semakin tinggi tingkat likuiditas maka nilai debt to equity ratioakan semakin menurun karena total hutang semakin berkurang akibat jangka panjang berkurang. Penelitian yang dilakukan oleh Stenyverens, dkk.(2018), menemukan bahwa likuiditasberpengaruh negatif 
terhadap struktur modal pada perusahaan. Dapat diambil kesimpulan bahwa likuiditas berpengaruh parsial terhadap struktur modal.

$\mathrm{H}_{3}$ : Ada pengaruh profitabilitas dan likuiditas terhadap struktur modal.

Profitabilitas dan likuiditas adalah ukuran dalam persentase yang digunakan untuk menilai sejauh mana perusahaan mampu mengatur pendanaan perusahaannya. Perusahaan dengan tingkat profitabilitas yang tinggi cenderung menggunakan hutang yang relatif sedikit. Menurut Brigham dan Houston (2012) faktor-faktor yang dapat mempengaruhi keputusan struktur modal adalah stabilitas penjualan, struktur aset, likuiditas, tingkat pertumbuhan, profitabilitas, pajak, kendali, sikap manajemen, sikap pemberi pinjaman dan pemeringkat, kondisi pasar, kondisi internal perusahaan serta fleksibilitas keuangan. Hasil penelitian Mikrawardhana (2015) menemukan bahwa secara bersama-sama menunjukkan bahwa profitabilitas, likuiditas berpengaruh signifikan terhadap struktur modal. Semakin tinggi nilai profitabilitas dan likuiditas maka akan diikuti dengan menurunnya rasio dari struktur modal. Dimana apabila perusahaan mampu menghasilkan laba (profitabilitas) maka perusahaan tersebut dipastikan akan mampu pula membayar hutang jangka pendek (likuiditas), sehingga pendanaan perusahaan tersebut dapat diatur dengan baik.

\section{Metode}

Rancangan penelitian yang digunakan dalam penelitian ini adalah kuantitatif kausal. Menurut Sugiyono (2014) penelitian kuantitatif kausal adalah penelitian yang bertujuan untuk menganalisis hubungan sebab-akibat antara variabel yang mempengaruhi dengan variabel yang dipengaruhi. Penelitian ini digunakan untuk menguji pengaruh profitabilitas dan likuiditas terhadap struktur modal pada perusahaan sub sektor property dan real estate yang terdaftar di Bursa Efek Indonesia. Adapun kriteria pengambilan sampel dalam penelitian ini adalah perusahaan-perusahaan yang menyertakan laporan keuangan yang lengkap tahun 2017-2018. Dalam penelitian ini objek yang digunakan adalah Perusahaan sub sektorproperty dan real estateyang terdaftar pada Bursa Efek Indonesia. Adapun subjek penelitian ini adalah profitabilitas $\left(\mathrm{X}_{1}\right)$, Likuiditas $\left(\mathrm{X}_{2}\right)$, Serta struktur modal $(\mathrm{Y})$.

Metode pengumpulan data yang digunakan dalam penelitian ini adalah pencatatan dokumen yaitu pengumpulan data dengan mengutip catatan atau dokumen pada neraca dan laba/rugi tahun 2017-2018 pada perusahaan sub sektor property dan real estate yang terdaftar di Bursa Efek Indonesia.

Teknik analisis data adalah analisis regresi linear berganda. Teknik dalam penelitian ini menggunakan bantuan program statistical package for social scene (SPSS) 23for windows untuk menjawab rumusan masalah dan menguji hipotesis yang diajukan.Tahapan yang dilakukan dalam teknik analisis regresi linear berganda dengan menggunakan SPSS for windows adalah dengan dilakukan uji asumsi klasik terlebih dahulu, dimana uji asumsi klasik merupakan syarat dari analisis regresi linear berganda. Uji asumsi klasik meliputi: (1) Uji Normalitas, (2) Uji multikolinearitas,(3) Uji autokorelasi, dan (4) Uji heteroskesdastisitas.

\section{Hasil dan Pembahasan Hasil}

Model analisis yang digunakan pada penelitian ini adalah analisis regresi linear berganda. Teknik ini digunakan untuk mencari ada atau tidaknya pengaruh variabel bebas yaitu profitabilitas dan likuiditas terhadap struktur modal pada perusahaan sektor property dan real estate yang terdaftar dalam Bursa Efek Indonesia dengan bantuan program aplikasi komputer Statistical Package for Social Science (SPSS) 23 for Windows.

Berikut merupakan ringkasan dari hasil output SPSS terkait pengujian pengaruh profitabilitas dan likuiditas terhadap struktur modal: 


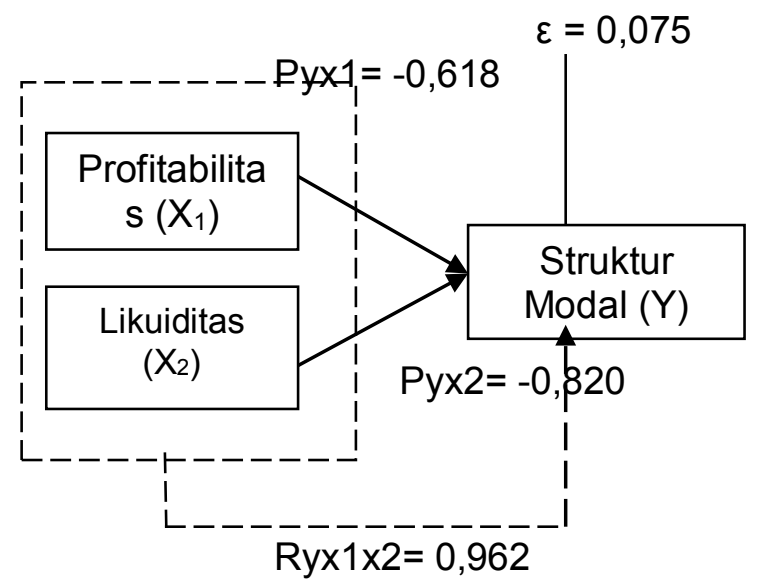

Gambar 1.1

Struktur pengaruh profitabilitas dan likuiditas terhadap struktur modal

Berdasarkan hasil uji regresi linear berganda (lampiran 8) diperoleh nilai konstanta (a) sebesar 109,148 . Nilai koefisien regresi dari profitabilitas $(\beta 1)$ adalah sebesar $-3,078$. Dan nilai koefisien regresi dari likuiditas $(\beta 2)$ sebesar $-0,392$. Sehingga persamaan regresi diformulasikan sebagai berikut:

$$
Y=109,148-3,078 X 1-0,392 X 2+\varepsilon
$$

Penjelasan hasil yang telah diformulasikan dari output SPSS adalah sebagai berikut:

1. Konstanta sebesar 109,148 berarti bahwa, apabila tingkat profitabilitas dan likuiditas nilainya sama dengan nol, maka struktur modal adalah sebesar 109,148. Maksudnya apabila tanpa melihat tingkat profitabilitas dan likuiditas maka struktur modal sebesar 109,148 rupiah.

2. Nilai koefisien profitabilitas sebesar $-3,078$ yang berarti tingkat profitabilitas berpengaruh negatif terhadap struktur modal. Setiap kenaikan profitabilitas satu satuan maka nilai struktur modal mengalami penurunan sebesar $-3,078$ sehingga menjadi 106,07 dengan asumsi variabel lainnya tetap.

3. Nilai koefisien tingkat likuiditas sebesar $-0,392$ yang berarti tingkat likuiditas berpengaruh negatif terhadap struktur modal. Setiap kenaikan likuiditas satu satuan maka nilai struktur modal mengalami penurunan sebesar $-0,392$ sehingga menjadi 108,756 dengan asumsi bahwa variabel lainnya tetap.

Nilai $\mathrm{Pyx}_{1}$ sebesar $-0,618$ menunjukkan bahwa koefisien tersebut tidak sama dengan nol, sehingga $\mathrm{HO}$ ditolak yang berarti terdapat pengaruh profitabilitas terhadap struktur modal. Nilai $p$-value sebesar $0,000<$ a 0,05 menunjukkan bahwa pengaruh dari profitabilitas terhadap struktur modal signifikan. Maka dapat disimpulkan bahwa profitabilitas berpengaruh signifikan terhadap struktur modal pada perusahaan sub sektor property dan real estate yang terdaftar dalam Bursa Efek Indonesia. Besar sumbangan pengaruh profitabilitas terhadap struktur modal adalah 0,381924 atau $38,19 \%$.

Nilai $\mathrm{Pyx}_{2}$ sebesar 0,820 menunjukkan bahwa koefisien tersebut tidak sama dengan nol, sehingga $\mathrm{HO}$ ditolak yang berarti terdapat pengaruh likuiditas terhadap struktur modal. Nilai $p-$ value sebesar 0,000 $<0,05$ menunjukkan bahwa pengaruh dari likuiditas terhadap struktur modal adalah signifikan. Maka dapat disimpulkan bahwa likuiditas berpengaruh signifikan terhadap struktur modal pada perusahaansub sektor property dan real estate yang terdaftar dalam Bursa Efek Indonesia. Besar sumbangan pengaruh likuiditas terhadap struktur modal adalah 0,06724 atau $6,72 \%$.

Nilai $\operatorname{Ryx}_{1} x_{2}$ sebesar 0,962 menunjukkan bahwa koefisien tersebut tidak sama dengan nol, sehingga $\mathrm{HO}$ ditolak yang berarti variabel profitabilitas dan likuiditas secara bersama-sama berpengaruh simultan terhadap struktur modal pada perusahaan sub sektor property dan real estate yang terdaftar dalam Bursa Efek Indonesia. Nilai $p$-value sebesar $0,000<0,05$ hal ini menujukkan bahwa ada pengaruh signifikan antara profitabilitas dan likuiditas terhadap struktur 
modal, dengan besar sumbangan pengaruh 0,925 atau 92,5\%. Hasil ini menunjukkan bahwa sebesar $92,5 \%$ struktur modal dipengaruhi oleh profitabilitas dan likuiditas, sedangkan sebesar $0,075 \%$ dipengaruhi oleh variabel lainnya yang tidak dibahas dalam penelitian ini.

\section{Pembahasan}

Berdasarkan hasil penelitian yang dilakukan dapat dijelaskan sebagai berikut: (1)Profitabilitas berpengaruh negatif dan signifikan terhadap struktur modal pada perusahaan sub sektor property dan real estate yang terdaftar dalam Bursa Efek Indonesia. Hal ini menunjukkan bahwa ketika nilai ROA tinggi maka akan berdampak pada menurunnya rasio dari struktur modal karena apabila perusahaan memiliki tingkat keuntungan yang tinggi maka perusahaan tersebut akan menggunakan laba ditahan yang dimiliki oleh perusahaannya untuk dijadikan sebagai modal perusahaan tersebut sehingga hal ini akan menurunkan nilai dari struktur modal. Profitabilitas merupakan rasio untuk menilai kemampuan perusahaan dalam mencari keuntungan. Perusahaan dengan tingkat return on assset yang tinggi, umumnya menggunakan hutang yang relatif sedikit, sehingga berpengaruh pada struktur modalWeston dan Brigham (2006:173). Hal ini sejalan dengan penelitian Mikrawardhana, dkk (2015), Dewiningrat, dkk (2018) yang menemukan bahwa profitabilitas berpengaruh negatif signifikan terhadap struktur modal. Namun bertentangan dengantemuan studi Watung (2016) bahwa profitabilitas berpengaruh positif terhadap struktur modal.

(2) Likuiditas berpengaruh negatif dan signifikan terhadap struktur modal pada perusahaan sub sektor property dan real estate yang terdaftar dalam Bursa Efek Indonesia. Hal ini menunjukkan bahwa semakin tinggi tingkat likuiditas maka nilai debt to equity ratio akan semakin menurun karena total hutang semakin berkurang akibat jangka panjang berkurang. Rasio likuiditas merupakan rasio yang menggambarkan kemampuan perusahaan untuk memenuhi kewajiban utang jangka pendek. Hasil penelitian ini mendukung Teori packing order Myers dan Majluf (1984) bahwa perusahaan lebih condong memilih mendanai perusahaan dengan dana internal, sehingga teori ini memprediksi adanya hubungan yang negatif antara likuiditas dan struktur modal.

Penelitian ini mendukung temuan studi Surjadi dan Sinambela (2017), Stenyverens, dkk. (2018) yang menemukan bahwa Likuiditas berpengaruh negatif terhadap struktur modal. Penelitian yang dilakukan oleh mikrawardhana, dkk (2015) yang menemukan bahwa likuiditas berpengaruh signifikan terhadap struktur modal.

(3) Profitabilitas dan likuiditas berpengaruh signifikan terhadap struktur modal pada perusahaan sub sektor property dan real estate yang terdaftar dalam Bursa Efek Indonesia. Hal ini menunjukkan bahwa profitabilitas dan likuiditas berpengaruh. Faktor-faktor yang mempengaruhi struktur modal adalah stabilitas penjualan, struktur aset, likuiditas, tingkat pertumbuhan, profitabilitas, pajak, kendali, sikap manajemen, kondisi pasar, kondisi internal perusahaan, fleksibilitas keuangan, sikap pemberi Pinjaman dan Lembaga Penilai PemeringkatBrigham dan Houston (2012). Hasil ini juga sejalan dengan temuan studi oleh Mikrawardhana, dkk (2015), Danang (2017) disebutkan bahwa secara simultan menunjukkan bahwa profitabilitas dan likuiditasberpengaruh signifikan terhadap struktur modal.

\section{Simpulan dan Saran Simpulan}

Berdasarkan pada hasil pengujian statistik dan hipotesis serta pembahasan yang telah dilakukan dapat ditarik kesimpulan sebagai berikut: (1) Profitabilitas berpengaruh negatif signifikan terhadap struktur modal pada perusahaan sub sektor property dan real estate yang tedaftar dalam Bursa Efek Indonesia. (2) Likuiditas berpengaruh negatif dan signifikan terhadap struktur modal pada perusahaan sub sektor property dan real estate yang tedaftar dalam Bursa Efek Indonesia. (3) Profitabiitas dan likuiditas berpengaruh signifikan terhadap struktur modal pada perusahaan sub sektor property dan real estate yang tedaftar dalam Bursa Efek Indonesia.

\section{Saran}

Berdasarkan hasil pembahasan dan simpulan yang diperoleh dalam penelitian ini, maka dapat diajukan beberapa saran sebagai berikut: (1) Bagi pihak manajemen dari perusahaan sub sektor property dan real estate yang terdaftar dalam Bursa Efek Indonesia hendaknya lebih 
memperhatikan lagi mengenai rasio likuiditas dan profitabilitas karena kedua variabel tersebut merupakan variabel yang signifikan dalam pengaruhnya terhadap naik turunnya struktur modal, terlebih lagi kedua variable ini berpengaruh negatif terhadap struktur modal sehingga perlu dikontrol agar tidak menimbulkan permasalahan dikemudian hari bagi perusahaan. (2) Bagi peneliti selanjutnya diharapkan menambah periode yang lebih panjang lagi dalam melakukan penelitian sehingga diperoleh gambaran lebih baik dalam jangka panjang serta menggunakan variabel yang lebih bervariasi dalam meneliti struktur modal sehingga data dapat dilihat dari segala aspek.

\section{Daftar pustaka}

Brigham, Eugene F dan Houston, Joel F. 2012. Dasar-dasar Manajemen Keuangan, diterjemahkan oleh Ali Akbar Yulianto. Edisi Kesebelas. Buku Kesatu. Jakarta: Salemba Empat.

Brigham, Eugene F. and Joel F. Houston. 2006. Dasar-Dasar Manajemen Keuangan. Buku 2. Edisi 11. Jakarta: Selemba Empat.

Brigham, Eugene F. Dan Houston. 2001. Manajemen Keuangan. Jakarta: Erlangga.

Danang. 2017. Pengaruh Profitabilitas, Likuiditas Dan Struktur Aktiva Terhadap Struktur Modal (Studi Pada Perusahaan Makanan Dan Minuman Yang Terdaftar Di BEl Pada Tahun 2012-2016). Artikel Skripsi Universitas Nusantara PGRI Kediri.Simki-Economic Vol. 01 No. 12. Hal.1-13.

David Sukardi Kodrat dan Christian Herdinata. 2009. Manajemen Keuangan. Yogyakarta: Graha IImu.

Dewiningrat dan Mustanda. 2018. Pengaruh Likuiditas, Profitabilitas, PertumbuhanPenjualan, Dan Struktur Aset Terhadap Struktur Modal Perusahaan Tekstil dan Garmen Yang Terdaftar Di Bursa Efek Indonesia Periode 2013-2016".E-Jurnal Manajemen Unud vol 7 No 7. Hal. 3486.

Husnan, Suad., dan Enny Pudjiastuti. 2012. Dasar-Dasar Manajemen Keuangan.Edisi Keenam. Yogyakarta: UPP (Unit Penerbit dan Percetakan (UPP STIM YKPN).

Kamaludin. dan Rini Indriani. 2012. Manajemen Keuangan. Edisi Revisi. Bandung. CV.Bandar Maju

Kasmir. 2010. Pengantar Manajemen Keuangan. Jakarta. Kencana Prenada Media Group.

Kasmir,2014. Analisis Laporan Keuangan, Edisis Pertama, Cetakan Ketujuh. Jakarta: PT.Rajagrafindo Perasda

Mikrawardhana, Hidayat,Azizah, 2015. Pengaruh Profitabilitas dan Likuiditas Terhadap Struktur Modal Perusahaan Multinasional (Studi Pada Perusahaan Multinasional yang Terdaftar di Bursa Efek Indonesia Tahun 2010-2013) Ilmu Administrasi Universitas Brawijaya Malang.

Muhadi. (2011).Penelitian Tindakan Kelas.Yogyakarta: Shira Media

Ozkan A. 2001. Determinans If Capital Structure of Listed Portuguese Companies. Determinans Of Dept Adjustmen. Review of Accounting and Finance. Vol 8 No.1

Sartono, Agus. 2012. Manajemen Keuangan Teori dan Aplikasi. Edisi Empat. Yogyakarta: BPFE.

Seftianne dan Handayani.2011. Faktor-Faktor yang Mempengaruhi Struktur Modal Pada Perusahaan Publik Sektor Manufaktur. Jurnal Bisnis dan Akuntansi, Volume 13 No. 1 April 2011, Halaman 39-56

Stenyverens, Paulina, Michael. 2018. 'Pengaruh Ukuran Perusahaa, Profitabilitas, Dan Likuiditas Terhadap Struktur Modal Pada Perusahaan Otomotif Yang Terdaftar Di Bursa Efek Indonesia Periode 2012-2015". Jurnal EMBA vol 6 No 1. Hal. 11-20.

Sugiyono. 2014. Metode Penelitian Administratif. Bandung. Alfabeta

Surjadi, Sinambela. 2016. "Faktor- Faktor Yang Mempengaruhi Struktur Modal Pada Perusahaan Manufaktur di Bursa Efek Indonesia 2012-2014”. Jurnal Akuntansi Bisnis. Vol. 9 No.2. Hal. 314-315.

Watung,2016. Pengaruh Rasio Likuiditas, Aktivitas, Profitabilitas, dan Struktur Aktiva Terhadap Struktur Modal Industri Barang Konsumsi di Bursa Efek Indonesia. Jurnal EMBA. Vol.4 No. 2 Juni. Hal. 726-737. 
Jurnal Prospek, Vol. 1 No. 2, Bulan Desember Tahun 2019

P-ISSN: 2685-5526

Yuliani. 2011. Leverage, Size and Age Mediating Bussiness Diversified to Financial Perfomance: Empirical Studies of Secondary Sectors in Indonesian Stock Exchage.Proceeding The 2nd International Conference Indonesian Management Scientists Association. Pekan Baru Riau. 2-4 Desember. 195212.http://eprints.unsri.ac.id/4718/diakses 19 April 2017. 